\title{
The importance of sampling scale in ecology: kilometer-wide variation in coral reef communities
}

\author{
Peter J. Edmunds*, John F. Bruno** \\ Department of Biology, California State University, 18111 Nordhoff Street, Northridge, California 91330, USA
}

\begin{abstract}
Observations along the north coast of Jamaica in 1994 suggested that areas of relatively high coral cover and high coral diversity occurred adjacent to reefs that have been in decline since 1980. This study was carried out to quantify these observations, to determine whether similar variation occurs elsewhere in the Caribbean, and to draw attention to the significance of kilometer-wide variation in coral reef community ecology. The fore reef (10 $\mathrm{m}$ depth) of Discovery Bay, Jamaica, had $<3 \%$ coral cover, 12 species of scleractinians and $>60 \%$ macroalgae cover and appeared typical of a highly degraded Caribbean reef. However, neighboring reefs $(<9 \mathrm{~km}$ away) in the same reef zone and at the same depth had up to 19 species of scleractinians, significantly higher coral cover ( 5 to $23 \%$ ) and lower macroalgae cover (10 to 39\%). Three reefs along the south coast of St. John, US Virgin Islands (10 m depth), which are protected within a National Park, displayed comparable kilometer-wide variation in coral cover ( 3 to $33 \%$ ) and macroalgae cover (22 to $33 \%$ ). The abundance of juvenile corals also displayed similar levels of kilometer-wide variation within both islands. These results demonstrate that several measures of coral reef community structure are highly variable over a spatial scale of kilometers; further study of these patterns may prove valuable in discerning the causes and consequences of coral demise. The existence of such large-scale variation emphasizes the importance of careful choice of sampling scale in the design and interpretation of monitoring programs in community ecology.
\end{abstract}

KEY WORDS: Coral - Reefs - Heterogeneity Scale

\section{INTRODUCTION}

The effect of sampling scale on the observed patterns of community structure has become a central issue in community ecology (Wiens 1989, Allen \& Hoekstra 1990, Menge \& Olson 1990, Levin 1992) that has attracted explicit attention and lively debate (Foster 1990, Paine 1991). These developments have been driven by studies in which the conclusions are affected by the scale of observation (Wiens 1989, Levin 1992), together with evidence that some biological phenomena are scale-independent (Aronson 1994). Although few studies have specifically examined a single process across several scales (see Aronson 1994, Ward \& Saltz 1994), the extrapolation from small- to large-

\section{·E-mail: peter.edmunds@csun.edu}

- Present address: Department of Ecology and Evolutionary Biology, Brown University, Providence, Rhode Island 02912, USA scale processes, without explicit sampling at the larger scale, is commonplace (Wiens 1989, Levin 1992). This problem has become more acute with the growing interest in temporal changes in community structure (Roemmich \& McGowan 1995) and their possible relationship with anthropogenic effects (e.g. Smith \& Buddemeier 1992). As a result, there is a growing penchant to extrapolate local studies to imply regional consequences (e.g. Barry et al. 1995) without addressing the spatial heterogeneity inherent in many ecosystems. Similar questions of scale are particularly germane to studies of tropical coral reefs (Jackson 1991), where scientists have long sought to explain patterns of diversity and community structure (Karlson \& Hurd 1993), and to determine the significance of natural and anthropogenic disturbances (Grigg \& Dollar 1991).

Tropical coral reefs are often affected by a variety of destructive phenomena such as storms (Connell 1973, Woodley et al. 1981), physiological stress (Glynn 1993) and diseases (Gladfelter 1982). As a result, descrip- 
tions of declining reef health are commonplace (Wilkinson 1992, Ginsburg 1994), and there can now be little doubt that many reefs have recently experienced a drastic reduction in coral cover and richness (Brown 1987, Porter \& Meier 1992, Ginsburg 1994, Hughes 1994), and a concomitant increase in algal cover (Lapointe 1989). However, the causes and consequences of changing reef communities remain contentious, particularly whether they are of natural or anthropogenic origin (Brown 1987), or whether the persistence of scleractinian corals through geological time and historic disturbances (MacIntyre 1988, Jackson 1992) should alleviate or accentuate concern.

The temporal and spatial scale of observation has been central to arguments of the significance of recent changes in coral reef community structure. While reefs appear to be more susceptible to disturbances and unpredictable on a time scale of decades (Liddell \& Ohlhorst 1992), some are known to persist over millennia (Jackson 1992). Similarly, although patterns and processes are often patchy on coral reefs (Grassle 1973, Edmunds \& Witman 1991), 'ecological anarchy' (Jackson 1991) over a quadrat scale can be replaced by order when larger scales are examined (Jackson 1991, Aronson \& Precht 1995). The interpretation of changes in coral community structure is made more complex by biases introduced by the selection of high coral cover, diverse and healthy reefs at the start of the monitoring program which can only remain unchanged or deteriorate once the study is initiated (Hughes 1992).

Studies of disturbance, stability and change on coral reefs are beginning to utilize landscape $\left(>10^{4} \mathrm{~m}^{2}\right.$; Aronson \& Precht 1995), regional (Wilkinson \& Cheshire 1988, Edmunds et al. 1990, Done 1992, Hughes 1994), decadal (Liddell \& Ohlhorst 1992, Dollar \& Tribble 1993, Hughes 1994) and millennial (Jackson 1992) scales to make general statements concerning trends in reef structure and function. However, as a result of design, local history or chance events such studies often emphasize the decline of previously healthy and well documented reefs without discussing the significance of remaining patches of relatively healthy reef. In 1994 we were impressed by the contrasts between descriptions of Caribbean-wide reef decline (e.g. Porter \& Meier 1992, Ginsburg 1994) and our own observations in St. John, US Virgin Islands and on reefs adjacent to Discovery Bay, Jamaica, where we found communities with comparatively high coral cover, high species richness and abundant juvenile corals. Our observations on the fore reef of Discovery Bay were similar to those previously recorded from the same site (Hughes 1994, Andres \& Witman 1995), but our observations on adjacent reefs suggested that considerable spatial variation in coral community structure was present over a scale of kilometers. Although spatial variation in reef communities has been detected in many studies (e.g. Rogers 1992, Aronson \& Precht 1995, Bak \& Nieuwland 1995), including the extensive surveys of Hughes (1994) along $300 \mathrm{~km}$ of the Jamaican coastline, the significance of spatial effects has received little explicit attention in coral ecology; it is possible that such variation might have considerable value in understanding the causes of change in reef community structure. Therefore, our goals in this study are to draw attention to: (a) the existence of a high degree of variation in coral community structure on a kilometer-wide scale, and (b) the significance of such spatial variation for coral reef ecology in particular, and community ecology in general. These goals are achieved through an among-site comparison of coral community structure using data collected specifically for this project, combined with data originally collected for other purposes.

\section{MATERIALS AND METHODS}

Field work was completed between May 1994 and January 1995 along the north coast of Jamaica and the south coast of St. John using facilities at the Discovery Bay Marine Laboratory (DBML) and the Virgin Islands Ecological Resource Station (VIERS), respectively. In Jamaica, 4 sites (10 $\mathrm{m}$ depth) were surveyed along $\sim 9 \mathrm{~km}$ of coastline extending to the east of Discovery Bay (Fig. 1). These sites were selected to encompass the variation in community structure we had observed in 1994: Mooring One (M1) was chosen as representative of the low cover, fore reef community at Discovery Bay (e.g. Andres \& Witman 1995), and because it is $<300 \mathrm{~m}$ from sites used in previous surveys (Liddell \& Ohlhorst 1987, Hughes 1994, Andres \& Witman 1995); Blowing Rocks (BR), Dairy Bull (DBL) and Silver Spray (SS) were chosen because previous observations suggested that these locations (Fig. 1) had relatively high coral cover and high coral richness compared to M1. Community structure was also quantified at 3 sites at $10 \mathrm{~m}$ depth in St. John, 1 at our long term site at Yawzi Point (YP) (Edmunds \& Witman 1991) and 2 others chosen using random map coordinates between White Point and Ram Head [White Point (WP) and West Tektite (WT); Fig. 1]. Five additional sites were haphazardly selected on shallow reefs ( $6 \mathrm{~m}$ depth) within the same area, and these were used to quantify the abundance of juvenile corals (Fig. 1).

Community structure was estimated with either a photographic or a point-intercept method (modified from Liddell \& Ohlhorst 1987) to determine the percentage of the reef occupied by macroalgae and scleractinian corals. Photoquadrats were recorded using a Nikonos V (with a $28 \mathrm{~mm}$ lens and strobes) mounted on 


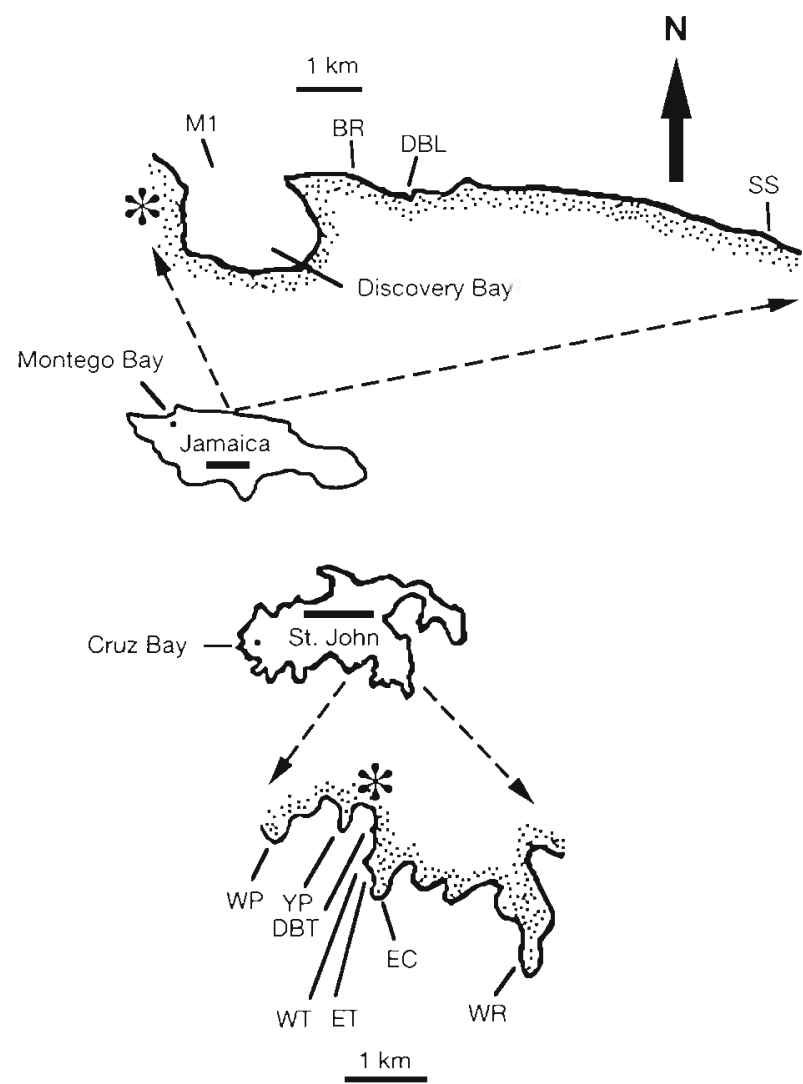

Fig. 1 Study sites along the north coast of Jamaica and the south coast of St. John, US Virgin Islands. Jamaica (island scale bar $=50 \mathrm{~km}$, all sites at $10 \mathrm{~m}$ depth): $\mathrm{BR}=$ Blowing Rocks, DBL $=$ Dairy Bull, M1 = Mooring One and SS $=$ Silver Spray. St. John (island scale bar $=5 \mathrm{~km}$ ): $10 \mathrm{~m}$ depth sites: $W P=$ White Point, $W T=$ West Tektite, $Y P=$ Yawzi Point $6 \mathrm{~m}$ depth sites: $\mathrm{DBT}=$ Donkey Bight, $\mathrm{EC}=$ East Cabritte $E T=$ East Tektite, $W P=$ White Point, $W R=$ West Ram Head * Location of marine laboratories

1 of 2 framers that allowed either $0.25 \mathrm{~m}^{2}$ or $0.75 \mathrm{~m}^{2}$ of reef to be recorded with a single exposure. The small framer was used to photograph quadrats at random positions along $20 \mathrm{~m}$ transects haphazardly placed along the $10 \mathrm{~m}$ contour at M1, DBL and SS in Jamaica (36 quadrats site ${ }^{-1}$ ) and WP and WT in St. John (17 quadrats site $^{-1}$ ). The large framer was used to photograph 10 quadrats positioned along each of 3 parallel $10 \mathrm{~m}$ transects at YP (total of 30 quadrats). Substrata were quantified by projecting the slides onto a screen, overlaying the image with a grid of 200 random dots, and counting the proportion of the dots that landed on each substratum. Community structure at BR, Jamaica, was determined with the point-intercept method. This method was also used at M1 to determine whether the point-intercept and the photographic methods yielded comparable results. At each site, five $10 \mathrm{~m}$ transects were placed at random along the $10 \mathrm{~m}$ depth contour, and the substratum beneath 100 points selected at ran- dom along each line was identified. The percentage of the substratum occupied by scleractinian corals and macroalgae was compared among sites using a nonparametric Kruskal-Wallis test because of the variation in methodology and sample size.

The density of coral recruits was estimated from the abundance of juveniles surveyed at 4 sites in Jamaica (10 $\mathrm{m}$ depth) and 5 sites in St. John (6 $\mathrm{m}$ depth). Juveniles were defined as colonies with a maximum diameter $\leq 4 \mathrm{~cm}$ which were $<3.5 \mathrm{yr}$ old (Bak \& Engel 1979); these were identified to genus since species identifications were unreliable. Juveniles were surveyed in quadrats randomly positioned along $20 \mathrm{~m}$ transect lines, and were counted wherever they were visible without removing algae. Forty $0.25 \mathrm{~m}^{2}$ quadrats were used at all sites except $B R$, where eight $1.0 \mathrm{~m}^{2}$ quadrats were randomly positioned along a $20 \mathrm{~m}$ transect line. The abundance of juveniles was compared among sites, within islands with a 1-way ANOVA.

To gain further insights to coral community structure, scleractinian species richness $(S)$ was determined as the asymptote to the curves obtained by plotting the cumulative species number against the number of quadrats surveyed. This analysis was only completed at M1, DBL and SS in Jamaica, where the same photographic methods were used and comparative data were available from adjacent reefs (Huston 1985). A similar approach was used to determine the generic richness $(G)$ of the juvenile population for the same 3 sites in Jamaica, together with the 5 shallow $(6 \mathrm{~m}$ depth) sites in St. John (Fig. 1).

Because of their potential role as important herbivores throughout the Caribbean (Carpenter 1986), the density of Diadema antillarum was measured by counting the number of urchins within $2 \times 20 \mathrm{~m}$ band transects ( $\mathrm{n}=3$ site $^{-1}$ ) at M1, DBL and BR in Jamaica. Both cryptic and conspicuous urchins were counted, and all transects were surveyed at 11:00 h to reduce the effects of diel variation in urchin abundance. Urchin densities were compared among sites with a 1-way ANOVA

\section{RESULTS}

The qualitative observations of variation in coral and macroalgal cover on the reefs adjacent to Discovery Bay were substantiated by quantitative analyses (Fig. 2). Coral cover varied by a factor of 11.5 (2 to $23 \%$ ) and macroalgae cover by a factor of 6.2 (10 to $62 \%$ ) within $9 \mathrm{~km}$ of the Discovery Bay fore reef, and both categories were significantly different among the 4 sites (coral: $H=54.322, \mathrm{df}=3, \mathrm{p}<0.001$; macroalgae: $H=66.842, \mathrm{df}=3, \mathrm{p}<0.001)$. The determinations of coral and macroalgae cover did not vary between 


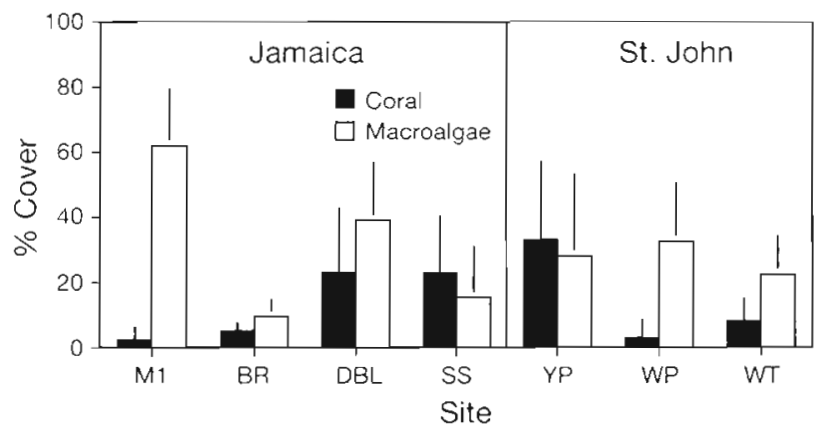

Fig. 2. Community composition of reefs at $10 \mathrm{~m}$ depth in Jamaica and St. John. Mean + SD shown for the percent cover of each substratum category, as calculated on untransformed data. Site codes as in Fig. 1

methods at M1 (Mann-Whitney $U$-test: $U \geq 141, \mathrm{df}=1$, $p>0.05$ ), demonstrating that similar results were obtained from the photographic and the point-intercept methods.

The magnitude of the differences in community structure among the 3 sites surveyed at $10 \mathrm{~m}$ depth in St. John (Fig. 2) was similar to that observed in Jamaica. Coral cover varied by a factor of 11.0 ( 3 to $33 \%$ ) and macroalgae cover by a factor of 1.5 (22 to $33 \%$ ) within $1 \mathrm{~km}$ of Yawzi Point. Although the percent cover of coral was significantly different among sites (Kruskal-Wallis test: $H=34.217, \mathrm{df}=2, \mathrm{p}=0.001$ ), the percent cover of macroalgae was not (Kruskal-Wallis test: $H=0.316, \mathrm{df}=2, \mathrm{p}>0.05$ ).

The abundance of juvenile corals (pooled for all 9 sites) varied between 0 and 22 per $0.25 \mathrm{~m}^{2}(0$ and 51 per $1.0 \mathrm{~m}^{2}$ quadrat at BR in Jamaica). These data provide within-island estimates of juvenile abundance ranging between $5.2 \pm 0.8$ and $17.9 \pm 1.8$ juveniles $\mathrm{m}^{-2}$ at the 4 sites in Jamaica, and $10.5 \pm 1.6$ to $18.1 \pm$ 2.3 juveniles $\mathrm{m}^{-2}$ at the 5 sites in St. John (all means $\pm \mathrm{SE}_{i}$ Fig. 3). Juvenile abundance was significantly different among sites in Jamaica $(F=54.745$; $\mathrm{df}=3,140$;
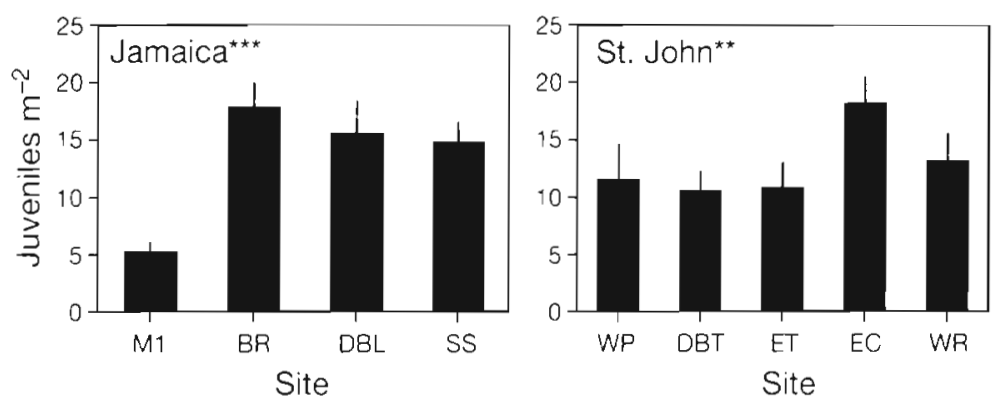

Fig. 3. Abundance of juvenile corals on reefs in Jamaica (10 $\mathrm{m}$ depth) and St. John ( $6 \mathrm{~m}$ depth). Mean + SE shown, $\mathrm{n}=40$ quadrats $\left(0.25 \mathrm{~m}^{2}\right)$ at each site except $B R$ where $n=8\left(1.00 \mathrm{~m}^{2}\right.$ quadrats $)$. Juvenile densities were significantly different among sites in both islands (ANOVA, ${ }^{* *} p<0.001$, ${ }^{*} p<0.011$. Site codes as in Fig. 1
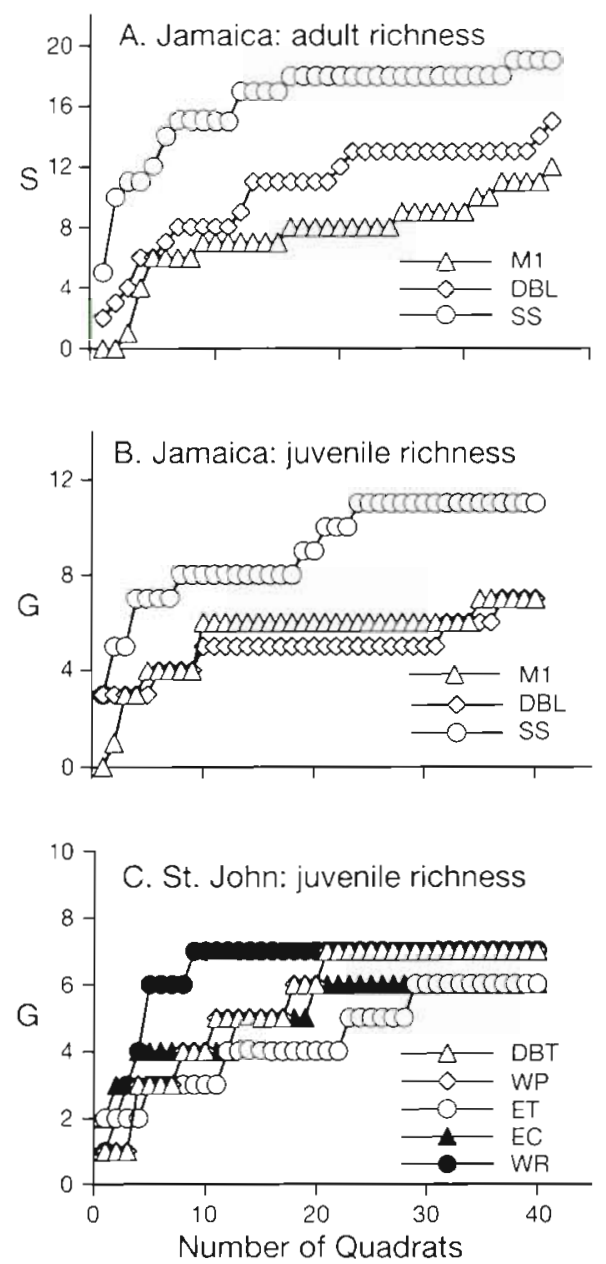

Fig. 4. Cumulative coral taxa encountered versus sampling effort for individual sites, within islands: (A) species richness $(S)$ of adults in Jamaica (10 $\mathrm{m}$ depth), (B) generic richness ( $G$ ) of juveniles in Jamaica (10 $\mathrm{m}$ depth), and (C) generic richness in St. John (6 $\mathrm{m}$ depth). Cumulative richness shown by quadrat as encountered in the field, note difference in scale of $G$ axis in (B) and (C). Site codes as in Fig. 1

$\mathrm{p}<0.001$ ), with $\mathrm{M} 1$ having the fewest juveniles (Fig. 3), and in St. John $(F=3.480$, $\mathrm{df}=4,195 ; \mathrm{p}<0.01)$.

The species and generic richness curves for the adult and juvenile scleractinians, respectively (Fig. 4), approached horizontal asymptotes at all sites, suggesting that estimates of richness were close to the actual values. Between 12 and 19 species of adult scleractinians were found at the 3 Jamaican sites which ranked as SS > DBL $>$ M1 by richness. When compared by generic richness, more genera of juvenile corals were found at $S S(G=11)$ than the other 2 sites ( $G=7$ at M1 and DBL), and a higher richness was found in Jamaica $[G=$ 
$8.3 \pm 1.3($ mean $\pm \mathrm{SE}, \mathrm{n}=3$ ); $10 \mathrm{~m}$ depth] than St. John $[G=6.6 \pm 0.4(n=3) ; 6 m$ depth], where between 6 and 7 genera were found at all 5 sites (Fig. 4). Mean densities of Diadema antillarum were $0.0 \pm 0.0,1.6 \pm 0.3$ and $2.1 \pm 0.6$ urchins $\mathrm{m}^{-2}$ at $\mathrm{M} 1, \mathrm{DBL}$ and $\mathrm{BR}$, respectively $( \pm \mathrm{SE}, \mathrm{n}=3$ at each site). These densities were significantly different when compared among sites $(F=$ $7.522 ; \mathrm{df}=2,6 ; \mathrm{p}<0.05)$

\section{DISCUSSION}

The dynamics of coral reef communities are now being studied throughout the tropics, and evidence of striking reductions in coral cover and richness has been recorded in many locations (Ginsburg 1994; see also citations in the 'Introduction'). Although many studies have also recorded a high degree of spatial heterogeneity in coral community structure, this level of variation has received little attention. As a result, we believe that investigations of the causes of reef decline may be overlooking potentially significant information available from an analysis of kilometer-wide variation in coral community structure.

The results of our surveys on the fore reef of Discovery Bay are concordant with those of Liddell \& Ohlhorst (1992), Hughes (1994), Andres \& Witman (1995) and many others for the same location. Clearly, this reef is now profoundly different from the reefs along the north coast of Jamaica first described by Goreau (1959), and from reefs at Discovery Bay as recently as 1980 (Liddell \& Ohlhorst 1992, Hughes 1994). However, adjacent reefs at $10 \mathrm{~m}$ depth have 5 to $23 \%$ coral cover, 19 species of scleractinians and 10 to $39 \%$ macroalgae cover. Coral cover at these sites is less than that recorded at the same depth on adjacent reefs prior to 1980 (42 to $75 \%$; Huston 1985, Hughes 1994), although species richness is higher than on the Discovery Bay fore reef in 1977 (10 m depth; Huston 1985) and 1980 (15 $\mathrm{m}$ depth; Liddell \& Ohlhorst 1987). Similar magnitudes of spatial variation were found in the distribution and generic richness of juvenile corals. For example, juveniles were rare at M1 (5 juveniles $\mathrm{m}^{-2}$ ) where the lowest coral and highest macroalgae cover were found, but they were more than 3 times as abundant at the other 4 sites ( 15 to 18 juveniles $\mathrm{m}^{-2}$ ). Similar spatial variation in coral community structure was also found in St. John. Since the St. John sites are located within the Virgin Islands National Park and are relatively free of anthropogenic disturbances, including unregulated fishing (Rogers \& Teytaud 1988), they demonstrate that kilometer-wide variation in community structure can be found irrespective of whether reefs are exposed to the severe anthropogenic effects implicated by the demise of Jamaican reefs (Hughes 1994).
Although benthic communities can be sampled at almost any scale, recent studies of Jamaican reefs have focused on a single study site, with a scale of tens of meters (Andres \& Witman 1995), or a whole island study with multiple-site sampling on a scale of tens of kilometers (Hughes 1994). The present study quantified reef structure on a kilometer-wide scale by comparing reefs $<9 \mathrm{~km}$ apart, and by repeating the analyses on 2 Caribbean islands differing in extent of anthropogenic influence. The studies of Andres \& Witman (1995) and Hughes (1994) both described patterns of low coral cover $(<5 \%)$ and high macroalgae cover on Jamaican reefs, although 1 site surveyed by Hughes (1994) had $\sim 20 \%$ coral cover. In contrast, sampling on a scale larger than that used by Andres \& Witman (1995) and smaller than Hughes (1994) revealed considerable variation in coral community structure in Jamaica and St. John; coral and macroalgae cover, coral recruitment, and adult and juvenile richness were all highly variable among adjacent reefs. Furthermore, Diadema densities ranged from being completely absent to values approaching those recorded throughout the Caribbean prior to 1983 (Bauer 1980). To determine the significance of these findings, the mechanisms underlying the observed patterns must now be elucidated (sensu Levin 1992).

Kilometer-wide variation in reef community structure could be driven by several related factors including local history, different rates of change of community structure and the patchy effects of stochastic events such as disturbances and larval recruitment. More than 1 factor may determine kilometer-wide patterns of coral and macroalgae cover, and different processes could control reef structure on different spatial scales. In Jamaica it is unclear how much variation existed among adjacent reefs in the recent past, but some records suggest it was considerable. For example, Huston (1985) surveyed reefs around Discovery Bay in 1977 and found $42 \%$ cover on the west fore reef and $27 \%$ cover on the east fore reef at $10 \mathrm{~m}$ depth. Since these analyses were completed prior to Hurricane Allen in 1980 (Woodley et al. 1981) and the Diadema die-off of 1983 (Hughes et al. 1985), they demonstrate the existence of spatial variation in fore reef communities prior to the start of the general decline of reefs along the north coast of Jamaica (Hughes 1994).

Spatial variation could also result from individual reefs being affected by the same processes functioning at different rates or by different processes. Severe disturbances caused by storms (Woodley et al. 1981), the removal of herbivores by overfishing (Russ 1991) or the catastrophic effects of disease on ecologically important species such as Diadema antillarum (Lessios et al. 1984) or Acropora palmata (Gladfelter 1982) are more 
likely to impact large areas of reef in a uniform way. Alternatively, similar processes of lesser magnitude, such as localized disease outbreaks (Peters 1984) or shoaling and refraction of storm waves (Kjerfve et al. 1986), might affect adjacent reefs in a dissimilar fashion, thereby creating substantial spatial heterogeneity in community structure. Variation in recruitment rates might also lead to spatial variation in community structure (Gaines \& Roughgarden 1985) either independent of, or together with, the effects of disturbance events. At the current time, the causes of the kilometer-wide variation in Jamaican reefs are unclear, due in part to the lack of information on their rates and directions of change in community structure. Nevertheless, the variation among these reefs, as well as among those on St. John, suggests that a better understanding of this scale of variation will have general application in reef ecology.

The results of this study neither contradict the findings of long-term studies of coral communities (e.g. Liddell \& Ohlhorst 1987, 1992, Hughes 1994), nor do they suggest that the relatively high coral cover reefs of the 1990s in Jamaica (Dairy Bull and Silver Spray) are unchanged compared to those found $25 \mathrm{yr}$ ago. Instead, they draw attention to the high variance in coral community structure that only becomes apparent when reefs are studied over a spatial scale of kilometers. Whether or not this variation is biologically significant will depend on the relative abundance of reefs with high coral cover and richness compared to those that are denuded, their proximity to one another, their hydrodynamic connectivity, their trajectories of community change (Johnson \& Preece 1992) and the degree of association between pattern and process in reef ecology. While no single scale can be considered 'correct' for systems analysis (Levin 1992), care should be taken in selecting the sampling scale for the question at hand, and caution should be used in 'scaling up' the results to scales that were not sampled. Finally, as suggested by Jackson (1991), our findings emphasize the need for further studies of kilometer-wide variation in coral communities; a better understanding of largescale processes might prove invaluable in formulating hypotheses to determine the causes and consequences of the decline in coral cover and coral richness of many reefs (Rogers 1992).

Acknowledgements. This work was supported in part by grants from the Office of Naval Research to P.J.E. (N0001493-1-0440), California State University at Northridge, the National Park Service Coral Reef Assessment Program and the East/West Marine Biology Program of Northeastern University. We thank M. Haley and the staff at the Discovery Bay Marine Laboratory (DBML) for laboratory space and facilities in Jamaica, C. Grippaldi and the staff at the Virgin Islands Environmental Resource Station for scientific amenities in
St. John and C.S. Rogers for continuous support of our work in the Virgin Islands. This research would not have been possible without the support of $P$. Janca to reach the Silver Spray reef and diving assistance from E. D. Keach. A. M. Melendy and D. W. Swanson. This manuscript was improved by comments from R. C. Carpenter, S. J. Genovese, G. H. Lenard, J. M. Levine and W. F. Precht. This is DBML contribution number 579 .

\section{LITERATURE CITED}

Allen TFH, Hoekstra TW (1990) The confusion between scaledefined levels and conventional levels of organization in ecology. J Veg Sci 1:5-12

Andres NG, Witman JD (1995) Trends in community structure on a Jamaica reef. Mar Ecol Prog Ser 118:305-310

Aronson RB (1994) Scale-independent biological processes in the marine environment. Oceanogr Mar Biol Annu Rev $32: 435-460$

Aronson RB, Precht WF (1995) Landscape patterns of reef coral diversity: a test of the intermediate disturbance hypothesis. J Exp Mar Biol Ecol 192:1-14

Bak RPM, Engel MS (1979) Distribution, abundance and survival of juvenile hermatypic corals (Scleractinia) and the importance of life history strategies in the parent community. Mar Biol 54:341-352

Bak RPM. Nieuwland G (1995) Long-term change in coral communities along depth gradients over leeward reefs in the Netherland Antilles. Bull Mar Sci 56:609-619

Barry JP, Baxter CH, Sagarin RD, Gilman SE (1995) Climaterelated, long-term faunal changes in a California rocky intertidal community. Science 267:672-675

Bauer JC (1980) Observations on geographical variations in population density of the echinoid Diadema antillarum within the western north Atlantic. Bull Mar Sci 30:509-515

Brown BE (1987) Worldwide death of corals-natural cyclical events or man-made pollution. Mar Pollut Bull 18:9-13

Carpenter RC (1986) Partitioning herbivory and its effects on coral reef algal communities. Ecol Monogr 56:345-363

Connell JH (1973) Population ecology of reef-building corals. In: Jones OA, Endean R (eds) Biology and geology of coral reefs, Vol 2. Academic Press, New York, p 205-245

Dollar SJ, Tribble GW (1993) Recurrent storm disturbance and recovery: a long-term study of coral communities in Hawaii. Coral Reefs 12:223-233

Done T (1992) Constancy and change in some Great Barrier Reef coral communities 1980-1990. Am Zool 32:655-662

Edmunds PJ, Roberts DA, Singer R (1990) Reefs of the northeastern Caribbean I. Scleractinian populations. Bull Mar Sci 46:780-789

Edmunds PJ, Witman JD (1991) Effect of Hurricane Hugo on the primary framework of a reef along the south shore of St. John, US Virgin Islands. Mar Ecol Prog Ser 78: 201-204

Foster MS (1990) Organization of macrnalgal assemblages in the northeast Pacific: the assumptions of homogeneity and the illusion of generality. Hydrobiologia 192:21-33

Gaines S, Roughgarden J (1985) Larval settlement rate: a leading determinant of structure in an ecological community of the marine intertidal. Proc Natl Acad Sci USA. 82:3707-3711

Ginsburg RN (compiler) (1994) Proceedings of the colloquium on global aspects of coral reets: health, hazards and history, 1993. Rosenstiel School of Marine and Atmospheric Sciences, University of Miami, Miami

Gladfelter WB (1982) White band disease in Acropora pal- 
mata: implications for the structure and growth of shallow reefs. Bull Mar Sci 32:639-643

Glynn PW (1993) Coral reef bleaching: ecological perspectives. Coral Reefs 12:1-18

Goreau TF (1959) The ecology of Jamaican coral reefs: species composition and zonation. Ecology 40:67-90

Grassle JF 11973) Variety in coral reef communities. In: Jones OA, Endean R (eds) Biology and geology of coral reefs, Vol 2. Academic Press, New York, p 247-270

Grigg RW, Dollar SJ (1991) Natural and anthropogenic disturbance on coral reefs. In: Dubinsky $Z$ (ed) Ecosystems of the world, Vol 25, Coral reefs. Elsevier, New York, p 439-452

Hughes TP (1992) Monitoring of coral reefs: a bandwagon? Reef Encoun 11:9-12

Hughes TP (1994) Catastrophes, phase shifts, and large scale degradation of a Caribbean coral reef. Science 265: $1547-1551$

Hughes TP, Keller BD, Jackson JBC, Boyle MJ (1985) Mass mortality of the echinoid Diadema antillarum Philippi in Jamaica. Bull Mar Sci 36:377-384

Huston M (1985) Patterns of species diversity in relation to depth at Discovery Bay, Jamaica. Bull Mar Sci 37: 928-935

Jackson JBC (1991) Adaptation and diversity of reef corals. BioSci 41:475-482

Jackson JBC (1992) Pleistocene perspectives on coral reef community structure. Am Zool 31:719-731

Johnson CR, Preece AL (1992) Damage, scale and recovery in model coral communities: the importance of system state. Proc 7th Int Coral Reef Symp, Guam 1:606-61.5

Karlson RH, Hurd LE (1993) Disturbance, coral reef communities, and changing ecological paradigms. Coral Reefs 12 : $117-126$

Kjerfve B, Magill KE, Porter JW, Woodley JD (1986) Hindcasting of hurricane characteristics and observed storm damage on a fringing reef, Jamaica, West Indies. J Mar Res 44:119-148

Lapointe BE (1989) Caribbean coral reefs: are they becoming algal reefs? Sea Front 35:82-91

Lessios HA, DR Robertson, Cubit JD (1984) Spread of Diadema mass mortalify through the Caribbean. Science 226:335-337

Levin SA (1992) The problem of pattern and scale in ecology. Ecology 73:1943-1967

Liddell WD, Ohlhorst SL (1987) Patterns of reef community structure, north Jamaica. Bull Mar Sci 40:311-329

Liddell WD, Ohlhorst SL (1992) Ten years of disturbance and

This article was presented by R. H. Karlson, Newark,

Delaware, USA change on a Jamaican fringing reef. Proc 7th Int Coral Reef Symp, Guam 1:144-150

Macintyre IG (1988) Modern coral reefs of western Atlantic: new geological perspective. Am Ass Petr Geol Bull 72: $1360-1369$

Menge BA, Olson AM (1990) Role of scale and environmental factors in regulation of community structure. Trends Ecol \& Evol 5:52-57

Paine RT (1991) Between Scylla and Charybdis: do some kinds of criticism merit a response? Oikos 61:90-92

Peters EC (1984) A survey of cellular reactions to environmental stress and disease in Caribbean scleractinian corals. Helgol Meeresunters 37:113-137

Porter J, Meier O (1992) Quantification of loss and change in Floridian reef coral populations. Am Zool 32:625-640

Roemmich D, McGowan J (1995) Climatic warming and the decline of zooplankton in the California current. Science $267: 1324-1326$

Rogers CS (1992) A matter of scale: damage from Hurricane Hugo (1989) to U.S. Virgin Islands reefs at the colony, community, and whole reef level. Proc 7 th Int Coral Reef Symp, Guam 1:127-133

Rogers CS, Teytaud R (1988) Marine and terrestrial ecosystems of the Virgin Islands National Park and Biosphere Reserve. Biosph Reserve Rep No 29, p 112

Russ GR (1991) Coral reef fisheries: effects and yields. In: Sale PF (ed) The ecology of fishes on coral reefs. Academic Press, San Diego, p 601-635

Smith SV, Buddemeier RW (1992) Global change and coral reef ecosystems. Annu Rev Ecol Syst 23:89-118

Ward D. Saltz D (1994) Foraging at different spatial scales: Dorcas gazelles foraging for lilies in the Negev desert. Ecology 75:48-58

Wiens JA (1989) Spatial scaling in ecology. Funct Ecol 3: $385-397$

Wilkinson CR (1992) Coral reefs of the world are facing widespread devastation: can we prevent this through sustainable management practices? Proc 7 th Int Coral Reef Symp, Guam 1:11-21

Wilkinson CR, Cheshire AC (1988) Cross-shelf variations in coral reef structure and function-influences of land and ocean. Proc 6th Int Coral Reef Symp, Tahiti 1:227-233

Woodley JD, Chornesky EA, Clifford PA, Jackson JBC, Kaufman LS, Knowlton N, Lang JC, Pearson MP, Porter JW, Rooney MC, Rylaarsdam KW, Tunnicliffe VJ, Wahle CM. Wulff JW, Curtis ASG, Dallmeyer MD, Jupp BP, Koehl MAR, Neigel J, Sides EM (1981) Hurricane Allen's impact on Jamaican coral reefs. Science 214:749-755

Manuscript first received: December 17, 1995

Revised version accepted: July 4, 1996 